\title{
Phytoremediation of organic pollutants in wastewater using native plants
}

\author{
Omayma N. Mohammed ${ }^{1, *}$, and Mohanad J. M-Ridha ${ }^{2}$ \\ ${ }^{1}$ Department of Environmental Engineering, University of Baghdad, Baghdad, Iraq, omaymanizar274@gmail.com \\ ${ }^{2}$ Department of Environmental Engineering, University of Baghdad, Baghdad, Iraq, muhannadenviro@coeng.uoBaghdad.edu.iq \\ *Omayma N. Mohammed, omaymanizar274@gmail.com \\ Published online: 30 June 2019
}

Abstract-Phytoremediation is a promising technology for the cleanup of petroleum contaminated soil. Total petroleum hydrocarbon TPH are elements of difficult management and they can cause carcinogenesis and toxicity in human. Different techniques have been used for the remediation of contaminated soils, but the phytoremediation is proposed as possible alternative, convenient and environmentally friendly than traditional physicochemical techniques. In this study two systems adopted; free surface flow (FSF) and subsurface flow (SSF) to select which system is more suitable for plant to be applied in future study of phytotoxicity test. The preliminary test for two types of plants phragmites communis (The scientific name is phragmites australis) and Helianthus annuus was conducted in a greenhouse for 14 days. The diesel concentrations used in this experiment were $(0,1,2,3,5) \% \mathrm{~V}_{\text {diesel }} / \mathrm{V}_{\text {water }}$ for both systems. Through this period the growth parameters measured; were wet weight, dry weight, stem length, root length and observation the withered for the two plants. From this work, SSF better than FSF and Phragmites communis is better in phytoremediation than Helianthus annuus.

Keywords - Phytoremediation, TPH, SSF, FSF, Phrammites communis, Helianthus annuus.

\section{Introduction}

Contamination of the aquatic environment has become an important and dangerous problem in many areas of the world with rivers and gulfs often affected in a serious way. Almost all marine coastal ecosystems have complicated structural and dynamic qualities that can be simply modified by human influence, estuarine and marine sediments are basins for different contaminants transported from other ecosystems. Total Petroleum Hydrocarbons (TPH's) as similate one of the most common groups of persistent organic pollutants in the environment. They have been studied much more because they are toxic to many organisms and human health [31].

Oil-producing and industrialized countries of the world are considered as a threat to the environment and to human health. Phytoremediation as a green technology selection, is particularly useful in wetland environments because it uses plants and their associated microorganisms to heal water contaminated with hydrocarbons, and it is more environmentally supporting than the traditional mechanical clean-up methods [7, 29]. The basic mechanisms in the phytoremediation of organic contaminants are the immediate understand of contaminants and their later metabolism in plant tissues, the transpiration of volatile organic hydrocarbons through the leaves, the launch of exudates that motivate microbial activity, and the improvement of mineralization at the root-soil interface, which is attributed to the microorganisms associated with the root surface [15][40]. Soil contamination petroleum hydrocarbons (PHC) is of concern according to potential adverse impacts on: (1) soil functions and services; (2) functional and structuralvariety of soil microorganisms, animals and plant communities and; (3) human health [8][25][26][49].

TPH is a mixture of many various compounds and everyone is exposed to TPH from many sources, including gasoline pumps, spilled oil on pavement, and chemicals used at home or work. Several of TPH compounds can affect your nervous system that leading to headaches and dizziness. TPH has been found in at least 23 of the 1,467 National Priorities List sites identified by the Environmental Protection Agency (EPA). Some chemicals that may be seen in TPH are hexane, jet fuels, mineral oils, benzene, toluene, xylenes, naphthalene, and fluorene, moreover other petroleum products and gasoline components [1]. Diesel is generally used fuel, basically in industry, and with the increase technological 
development, it has become one of the most popular organic pollutants in the environment as well as it is toxic to a lot of organisms and detrimental to human health [31]. Phytoremediation for wastewater treatment uses plants species to break down, convert, digest, or removal toxic pollutants [13] and it is a natural mixing technology between plants and microbes to remediate contaminated site[22]. Recently, phytoremediation has been used to remediate industrial wastewater contam- inated by organochlorines, including chlorobenzenes, chlorophenols, chlorinated hydrocarbons and chlorinateed olefins [37]. The application of phytoremedi-ation in recent years has changed the environment to the better using efficient and cheap in situ methods[15]. The aim of this study is to determine the maximum concentration of diesel which phragmites communis and Helianthus annuus plants that can survive and degrade the hydrocarbons.

\section{Advantages and limitations of the phytore me diation te chnology}

The advantages and limitations of the phytoremediation technology is:

Table 1: Advantages and limitations of phytoremediation [16].

\begin{tabular}{|c|c|}
\hline Advantages & Limitations \\
\hline $\begin{array}{l}\text { Applicable to wide } \\
\text { variety of inorganic and } \\
\text { organic contaminants. }\end{array}$ & $\begin{array}{l}\text { Limited by depth (roots) } \\
\text { and solubility and } \\
\text { availability of the } \\
\text { contaminant. }\end{array}$ \\
\hline $\begin{array}{l}\text { Reduces the a mount of } \\
\text { waste going to landfills. }\end{array}$ & $\begin{array}{l}\text { Although faster than } \\
\text { natural attenuation, it } \\
\text { requires long time } \\
\text { periods (several years). }\end{array}$ \\
\hline 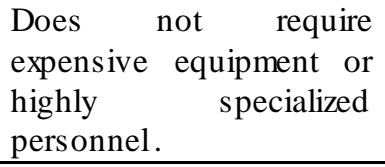 & $\begin{array}{l}\text { Restricted to sites with } \\
\text { low contaminant } \\
\text { concentration. }\end{array}$ \\
\hline $\begin{array}{l}\text { It can be applied in situ, } \\
\text { Reduces soil disturbance } \\
\text { and the spread of } \\
\text { contaminants. }\end{array}$ & $\begin{array}{l}\text { Plant biomass } \\
\text { phytoextraction requires } \\
\text { proper disposal as } \\
\text { hazardous waste. }\end{array}$ \\
\hline $\begin{array}{l}\text { Early estimates of the } \\
\text { costs indicate that } \\
\text { phytoremediation is } \\
\text { cheaperthan conventional } \\
\text { remediation methods. }\end{array}$ & $\begin{array}{l}\text { Climate and season } \\
\text { dependent. It can also } \\
\text { lose its effectiveness } \\
\text { when damage occurs to } \\
\text { the vegetation from } \\
\text { disease or pests }\end{array}$ \\
\hline $\begin{array}{l}\text { Easy to implement and } \\
\text { maintain . Plants are a } \\
\text { cheap and renewable } \\
\text { resource . easily available } \\
\text {. }\end{array}$ & $\begin{array}{l}\text { Introduction of } \\
\text { inappropriate or invasive } \\
\text { plant species should be } \\
\text { avoided (non-native } \\
\text { species may affect } \\
\text { biodiversity). }\end{array}$ \\
\hline $\begin{array}{l}\text { Environmentally friendly } \\
\text {. aesthetically pleasing . } \\
\text { socially accepted . low- } \\
\text { tech alternative. }\end{array}$ & $\begin{array}{l}\text { Contaminants may be } \\
\text { transferred to another } \\
\text { medium , the } \\
\text { environment . and or the } \\
\text { food chain. }\end{array}$ \\
\hline
\end{tabular}

\begin{tabular}{|l|lr|}
\hline Less noisy than other & Amendments & and \\
remediation methods. & cultivation practices \\
Actually trees may reduce & may have negative \\
noise from industrial & consequences & on \\
activities & contaminant mobility. \\
\hline
\end{tabular}

\section{Mechanisms of phytoremediation}

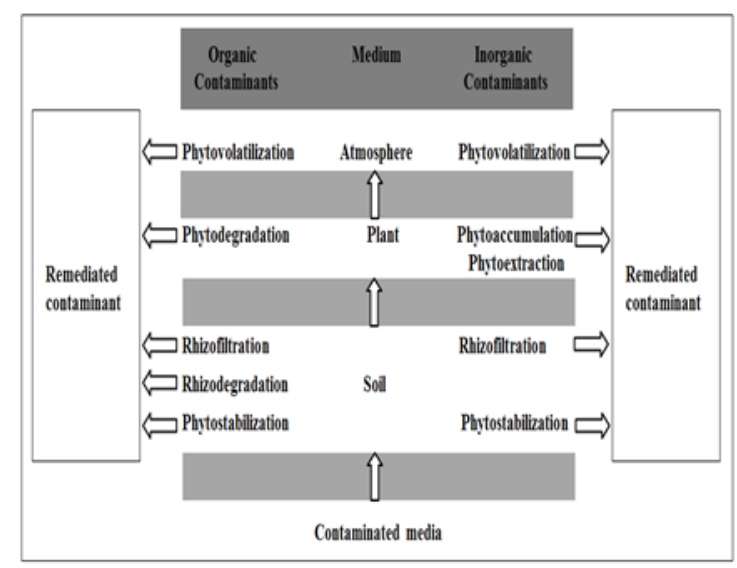

Figure 1: Mechanisms of phytoremediation [46].

\subsection{Phytoextraction}

Phytoextraction is a technique used in situ for the treatment of contaminated soils [2] [6] [24] [34] [49]. Contaminants are being absorbed by the roots, transported and accumulated in the shoots and leaves [30,44]. Phytoextraction is an eco-friendly technology and has many important advantages:

- It does not destroy/change the landscape.

- It protects the conservation and so the ecosystem.

- It is the major technique of phytoremediation to the removal of heavy metals from soil, sediment and water.

- It is also regarded as the most commercially hopeful technique because it is cheap [3].

\subsection{Phytostabilization}

Pollutants are immobilized in the root system by absorption of the roots or precipitation in the rhizosphere, so this process reduces the contaminant mobility, inhibiting migration into groundwater and reduce the bioavailability in the food chain $[2,6,42,49]$.

The advantage of this technique consists:

In the changes of soil chemistry composition happened by existence of the plant itself and such these changes can facilitate the absorption or cause the precipitation of metals on the roots [51].

\subsection{Phytovolatilization}

In phytovolatilization process the pollutants are absorbed at root level and moved by the xylem and emitted into the atmosphere from the aerial parts of plant in less toxic forms because of metabolic modification. So, pollutants 
are not only removed but they are being moved from one part to another[2, 6, 42, 49].

The most advantage of this technique is the probability that the contaminant can be changed into a less toxic substance, but, on the otherhand, the weakness of this application is the probability that the modified substance, and still potentially toxic, can be emitted into atmosphere and then resettling in to the environment.

The phytovolatilization can be stratified to contaminants existence in soil, sediment or water, especially for organic contaminants like tetrachloroethane, trichloromethane and tetrachloromethane [39, 45, 52].

\subsection{Phytodegradation}

In Phytodegradation process, organic contaminants, after absorption by the root system, are degraded gratitude to the activity that completed by enzymes contributed in metabolism of the plant, or they will be incorporated into the plant tissues [2, 6, 42, 49]. Contaminants are stopped working after they have been started by the plant. As with phytoextraction and phytovolatilization, plant absorbtion generally happens only when the contaminants' solubility and hydrophobicity fall into a particular acceptable range. Phytodegradation has been noticed to remediate some organic contaminants, like chlorinated solvents, herbicides, and munitions, so it can treat contaminants in soil, sediments, or groundwater [48].

\subsection{Rhizofiltration}

Rhizofiltration allows the removal of organic and inorganic pollutants from groundwater, surface water as well as wastewater either adsorption or precipitation on the roots, or for adsorption of contaminants around the root zone [51]. Several disadvantages of this technique consist in: adjust the $\mathrm{pH}$, the importance of a first cultivation in a greenhouse, frequent harves ts and subsequent get rid of the plants $[6,42]$.

\subsection{Rhizodegradation}

Rhizodegradation consists in the biodegradation of the organic contaminants at level of the radical apparatus of the plant, in a soil area called rhizosphere and this process happens gratitude to the activity of bacteria, fungi and yeasts (several studies have shown that the number of microorganisms in the rhizosphere is 100 times greater than the quantity present on the surface), that take out nutrients from the root exudates of the plant. Root exudates are a carbon and nitrogen source, and these root exudates are able to increase the efficiency of extraction and after that removal of contaminants via the plant $[6,12,27,28$, 49]. Among the advantages and disadvantage [9][11][24][43]:

- It is a process, which happens in situ;

- Trans location of the compounds to other parts of the plant or in the atmosphere is lesser than other technologies of phytoremediation.

- It can get a perfect mineralization.

- Installation and maintenance costs are low.

The disadvantages is:

- It is a slow process and efficient only on surface of contamination (20-25 cm of depth).

- The depth of the roots may be specified by the physical structure of soil.

- Plants may demand fertilizer.

Table 2: Phytoremediation studies on the treatment of pollutants

\begin{tabular}{|c|c|c|c|c|c|c|}
\hline Author & $\begin{array}{c}\text { Image } \\
\text { of } \\
\text { plant }\end{array}$ & Species & $\begin{array}{l}\text { Type of } \\
\text { system }\end{array}$ & $\begin{array}{c}\text { Concentration of } \\
\text { pollutant }\end{array}$ & $\begin{array}{c}\text { Methods } \\
\text { (Period time, } \\
\text { PH,T,Q,Temp.) }\end{array}$ & $\begin{array}{l}\text { Removal } \\
\text { efficiency }\end{array}$ \\
\hline $\begin{array}{c}\text { Israa } \\
\text { Abdulwahab } \\
\text { Al-Baldawi } \\
\text { et al. 2013 } \\
{[20]}\end{array}$ & & $\begin{array}{l}\text { Bulrush of } \\
\text { scirpus } \\
\text { grosses }\end{array}$ & $\begin{array}{c}\text { Sub surface } \\
\text { (horizontal) } \\
\text { Emergent } \\
\text { plant }\end{array}$ & $\begin{array}{c}\text { Diesel } \\
(0,0.1,0.2,0.25)^{\%} \\
\text { V diesel/V water }\end{array}$ & $\begin{array}{c}\mathrm{T}=72 \text { days } \\
\text { Temp }=24-27 \mathrm{c}^{\mathrm{o}} \\
\mathrm{pH}=5.6-6.4 \\
\text { for } 0 \\
\mathrm{pH}=5.2-8.4 \\
\text { for all }\end{array}$ & $\begin{array}{l}\text { eff. } 0.1=82 \% \\
\text { eff. } 0.2=71 \% \\
\text { eff. } 0.25=67 \%\end{array}$ \\
\hline $\begin{array}{l}\text { Asmita V. } \\
\text { Potil Jyoti } \\
\text { P. Jedhav } \\
2013 \\
{[5]}\end{array}$ & & $\begin{array}{l}\text { Tagetes } \\
\text { patula L. }\end{array}$ & ----- & $\begin{array}{l}\text { Textile dye Reactive } \\
\text { blue } 160(20-100) \frac{m g}{l}\end{array}$ & $\begin{array}{c}\mathrm{T}=3 \text { weeks } \\
\text { temp. }=25 \pm 2 \\
\mathrm{pH}=5.8\end{array}$ & $\begin{array}{l}\text { eff.at20 } \frac{m g}{l}=90 \% \\
\text { eff.at } 40 \frac{m g}{l}=74 \% \\
\text { eff.at60 } \frac{m g}{l}=67 \% \\
\text { eff.at80 } \frac{m g}{l}=62 \% \\
\text { eff.at } 100 \frac{m g}{l}=57 \%\end{array}$ \\
\hline $\begin{array}{l}\text { Nadya } \\
\text { H.A.S } \\
\text { et al. } 2014 \\
\text { [33] }\end{array}$ & & $\begin{array}{l}\text { Elecocharis } \\
\text { ochrostochys }\end{array}$ & $\begin{array}{c}\text { Sub surface } \\
\text { Free } \\
\text { surface }\end{array}$ & $\begin{array}{c}\text { Diesel } \\
(0,5,10,20,30,40) \\
\text { ml Diesel/L water }\end{array}$ & $\mathrm{T}=15$ days & $\begin{array}{c}\text { bulrush resistant } \\
\text { hydrocarbons } \\
\text { SSF systemwas } \\
\text { batter compared } \\
\text { FSF }\end{array}$ \\
\hline
\end{tabular}




\begin{tabular}{|c|c|c|c|c|c|c|}
\hline $\begin{array}{l}\text { Ray R. } \\
\text { Hinchman } \\
\text { et. al } \\
\text { [35] }\end{array}$ & $(x)$ & $\begin{array}{l}\text { Hybrid polar } \\
\text { (Populus sp.) }\end{array}$ & $\begin{array}{l}\text { Sub surface } \\
\text { horizontal } \\
\text { and vertical }\end{array}$ & $\begin{array}{l}\text { Heavy metal (zinc) } \\
\qquad 50-2000\left(\frac{\mu g}{g}\right)\end{array}$ & -- & $\begin{array}{c}\text { For Hybrid polar } \\
\text { eff. }=99 \%\end{array}$ \\
\hline $\begin{array}{c}\text { Ray R. } \\
\text { Hinchman } \\
\text { et. al } \\
\text { [35] }\end{array}$ & & $\begin{array}{c}\text { Eastern } \\
\text { Gamagarass } \\
\text { (Tripsacum } \\
\text { dactyloides) }\end{array}$ & $\begin{array}{l}\text { Sub surface } \\
\text { horizontal } \\
\text { and vertical }\end{array}$ & $\begin{array}{l}\text { Heavy metal (zinc) } \\
\qquad 50-2000\left(\frac{\mu g}{g}\right)\end{array}$ & & $\begin{array}{l}\text { for Eastern } \\
\text { eff. }=(90-50) \%\end{array}$ \\
\hline $\begin{array}{c}\text { Israa } \\
\text { Abdulwahab } \\
\text { Al-Baldawi } \\
2015 \\
{[18]}\end{array}$ & & $\begin{array}{c}\text { Typha } \\
\text { angustifolia }\end{array}$ & $\begin{array}{l}\text { Sub surface } \\
\text { (horizontal) }\end{array}$ & $\begin{array}{c}\mathrm{COD} \\
\mathrm{TSS} \\
\mathrm{NH}_{4}-\mathrm{N} \\
\mathrm{NO}_{3}-\mathrm{N}\end{array}$ & $\begin{array}{c}\mathrm{T}=95 \text { days } \\
\text { temp. }=25-33 \mathrm{c}^{\mathrm{o}} \\
\mathrm{pH}=4.5 \pm 0.1\end{array}$ & $\begin{array}{c}\text { eff.TSS }=(73.3- \\
95.5) \% \\
\text { eff.COD }=(35.2- \\
86) \% \\
\text { eff.NH4 }=33.9 \% \\
97.2 \% \\
18.9 \% \\
\text { eff. } 1 \text {. } 3=79.6 \% \\
85.5 \% \\
71.8 \%\end{array}$ \\
\hline $\begin{array}{c}\text { Kah Aik Jan } \\
\text { et al. } 2016 \\
{[23]}\end{array}$ & & $\begin{array}{l}\text { Eichhornia } \\
\text { crassipes }\end{array}$ & $\begin{array}{l}\text { free } \\
\text { floating } \\
\text { plant }\end{array}$ & $\begin{array}{l}\text { dyes Methylene blue } \\
\text { Methyl orange } \\
(5,100,150,200) \frac{\mathrm{mg}}{l}\end{array}$ & $\begin{array}{c}\mathrm{T}=20 \text { days } \\
\text { temp. }=30 \pm 1 \mathrm{c}^{\mathrm{o}} \\
\mathrm{pH}=4.4-10 \\
\mathrm{Q}=50 \frac{\mathrm{mg}}{\mathrm{l}}\end{array}$ & $\begin{array}{c}\text { eff.MB }=98.42 \% \\
\text { eff. } . \mathrm{MO}=66.8 \%\end{array}$ \\
\hline $\begin{array}{c}\text { Israa } \\
\text { Abdulwahab } \\
\text { Al-Baldawi } \\
\text { et al. 2013 } \\
{[17]}\end{array}$ & & $\begin{array}{l}\text { scirpus } \\
\text { grosses }\end{array}$ & $\begin{array}{l}\text { Sub surface } \\
\text { Free } \\
\text { surface } \\
\text { emergent } \\
\text { plant }\end{array}$ & $\begin{array}{c}\text { Diesel }(1.2 .3) \% \\
\mathrm{~V} \text { diesel/V water }\end{array}$ & $\begin{array}{c}\mathrm{T}=72 \text { days } \\
\text { temp } \mathrm{SSF}=27.96 \\
\mathrm{pH} \mathrm{SSF}=5.27 \\
\text { temp }{ }_{\mathrm{FSF}}=25.96 \\
\mathrm{pH} \mathrm{FSF}=6.5\end{array}$ & $\begin{array}{l}\text { eff. } \text { SSF}=91.5 \% \\
\text { eff. } \mathrm{FSF}=80.2 \%\end{array}$ \\
\hline $\begin{array}{c}\text { Salmi Nur } \\
\text { Ain Sanusi } \\
\text { et al. } 2012 \\
{[38]}\end{array}$ & & $\begin{array}{l}\text { paspalum } \\
\text { vaginatum }\end{array}$ & $\begin{array}{c}\text { Free } \\
\text { surface }\end{array}$ & $\begin{array}{c}\text { Diesel } \\
(5,10,15,20,25,30) \frac{g}{k g}\end{array}$ & $\mathrm{~T}=28$ days & $\begin{array}{l}\text { The plant could } \\
\text { grow and has the } \\
\text { potential in the } \\
\text { phytoremediation } \\
\text { of hydrocarbons } \\
\text { range } \\
(0-30) \frac{\mathrm{g}}{\mathrm{kg}}\end{array}$ \\
\hline $\begin{array}{c}\text { Israa } \\
\text { Abdulwahab } \\
\text { Al-Baldawi } \\
\text { et al. 2015 } \\
{[19]}\end{array}$ & & $\begin{array}{l}\text { scirpus } \\
\text { grosses }\end{array}$ & $\begin{array}{l}\text { Sub surface } \\
\text { emergent } \\
\text { plant }\end{array}$ & $\begin{array}{c}\text { Diesel } \\
(0,1.0,1.0 .175,0.25) \% \\
\text { V diesel/V water }\end{array}$ & $\begin{array}{c}\mathrm{T}=72 \text { days } \\
\text { temp. }=30 \pm 3 \mathrm{c}^{\mathrm{o}}\end{array}$ & $\begin{array}{c}\text { eff. } 0.1=81.5 \% \\
\text { eff. } 0.175=71.4 \% \\
\text { eff. } 0.25=66.6 \%\end{array}$ \\
\hline $\begin{array}{c}\text { Israa } \\
\text { Abdulwahab } \\
\text { Al-Baldawi } \\
\text { et al. } 2013 \\
{[21]}\end{array}$ & & $\begin{array}{l}\text { scirpus } \\
\text { grosses }\end{array}$ & $\begin{array}{l}\text { Sub surface } \\
\text { Horizontal } \\
\text { emergent } \\
\text { plant }\end{array}$ & $\begin{array}{c}\text { Diesel } \\
(0,8700,17400,26100) \\
\frac{m g}{l}\end{array}$ & $\begin{array}{c}\mathrm{T}=72 \text { days } \\
\text { Temp. }=24.28 \mathrm{c}^{\mathrm{o}} \\
\mathrm{pH}=5.9-7.6 \\
\mathrm{Q}=7 \mathrm{~L}\end{array}$ & $\begin{array}{l}\text { eff. for range } \\
(67.2-69.9) \%\end{array}$ \\
\hline $\begin{array}{l}\text { Nadali } \\
\text { Alavi } \\
\text { et al. } \\
\text { [32] }\end{array}$ & & $\begin{array}{l}\text { Sorghum } \\
\text { halepenes } \\
\text { (L.) pers. }\end{array}$ & $\begin{array}{l}\text { Sub surface } \\
\text { emergent } \\
\text { plant }\end{array}$ & $\begin{array}{c}\text { TPH }(5,10,25,50,100) \\
\frac{g}{k g}\end{array}$ & $\begin{array}{l}\text { temp. }=25 \pm 5 \\
\mathrm{~T}=180 \text { days }\end{array}$ & eff. Sorghum $=86 \%$ \\
\hline
\end{tabular}




\begin{tabular}{|c|c|c|c|c|c|c|}
\hline $\begin{array}{c}\text { Nadali } \\
\text { Alavi } \\
\text { et al } \\
\text { [32] }\end{array}$ & $\begin{array}{l}1 \\
2 y+2 \\
y+1\end{array}$ & $\begin{array}{c}\text { pers. } \\
\text { Aeluropus } \\
\text { littoralis } \\
\text { (Guna) parl. }\end{array}$ & $\begin{array}{c}\text { Sub surface } \\
\text { emergent } \\
\text { plant }\end{array}$ & $\begin{array}{c}\text { TPH }(5,10,25,50,100) \\
\frac{g}{k g}\end{array}$ & $\begin{array}{l}\text { temp. }=25 \pm 5 \\
\mathrm{~T}=180 \text { days }\end{array}$ & eff. Aeluropus $=43 \%$ \\
\hline $\begin{array}{c}\text { Eman A. } \\
\text { Diab } \\
2008 \\
{[10]}\end{array}$ & & $\begin{array}{l}\text { Vicia faba } \\
\text { zea mays }\end{array}$ & $\begin{array}{l}\text { Free } \\
\text { surface }\end{array}$ & $\begin{array}{c}\text { TPH }(2.2-2.3) \% \text { oil } \\
\text { V diesel/V water }\end{array}$ & $\begin{array}{l}\mathrm{T}=60 \text { days } \\
\mathrm{pH}=7.6-7.8\end{array}$ & eff. $=62.4 \%$ \\
\hline $\begin{array}{c}\text { Eman A. } \\
\text { Diab } \\
2008 \\
{[10]}\end{array}$ & & Triticum & $\begin{array}{l}\text { Free } \\
\text { surface }\end{array}$ & $\begin{array}{c}\text { TPH }(2.2-2.3) \% \text { oil } \\
\mathrm{V} \text { diesel/V water }\end{array}$ & $\begin{array}{l}\mathrm{T}=60 \text { days } \\
\mathrm{pH}=7.6-7.8\end{array}$ & eff. $=19.9 \%$ \\
\hline $\begin{array}{c}\text { Eman A. } \\
\text { Diab } \\
2008 \\
{[10]}\end{array}$ & & aestivuml & $\begin{array}{c}\text { Free } \\
\text { surface }\end{array}$ & $\begin{array}{l}\text { TPH }(2.2-2.3) \% \text { oil } \\
\text { V diesel/V water }\end{array}$ & $\begin{array}{l}\mathrm{T}=60 \text { days } \\
\mathrm{pH}=7.6-7.8\end{array}$ & eff. $=17.6 \%$ \\
\hline $\begin{array}{c}\text { Asia Fadhile } \\
\text { Al- } \\
\text { Mansoory } \\
\text { Et al. 2015 } \\
\text { [4] }\end{array}$ & 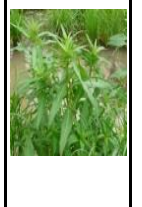 & $\begin{array}{l}\text { Ludwigia } \\
\text { Octovalvis } \\
\text { (jacq.) }\end{array}$ & $\begin{array}{c}\text { Free } \\
\text { surface }\end{array}$ & $\begin{array}{l}\text { TPH }(1,2,3) \% \frac{g}{k g} \\
\mathrm{~V} \text { diesel/V water }\end{array}$ & $\mathrm{T}=72$ days & eff. $=79.81 \%$ \\
\hline
\end{tabular}

\section{Methodology}

\section{a. Plant Propagation}

Phragmites communis and Helianthus annuus were propagated for 6 weeks in the same number of selected plants of (phragmites communis, Helianthus annuus) having the same size, were used in each test pail for each species during propagation, the growth parameters measured were wet weight, dry weight, roots length and stem height.

\section{b. Determination of Wet Weight}

Two plants were combined at each sampling time and were rinsed with tap water then the water was absorbed onto tissue paper and the wet weight was recorded [41].

\section{c. Determination of Dry Weight}

Plants were dried in an oven at $70 \mathrm{c}^{\circ}$ for $72 \mathrm{~h}$, after that dry weight was [41][47].

\section{d. Measurement of Root Length and Stem Height}

Root length was measured from the plant at ground level to the root tip, however plant height was determined starting from ground-height to the tip of the longest stems or leaves [14][36].

\section{Preliminary tests}

The preliminary test was tested in the same number of selected plants of (phragmites communis, Helianthus annus) having the same size, were used in each test pail for each species. Synthetic wastewater was prepared by mixing water with diesel in different percentages concentrations $1,2,3,5 \% \quad\left(\mathrm{~V}_{\text {diesel }} / \mathrm{V}_{\mathrm{water}}\right)$. In this study, freesurface flow (FSF) and sub-surface flow (SSF) systems were used to determine a flow system that enabled the plant to tolerate diesel.

Each pail was planted with plants of the plant in $3 \mathrm{~kg}$ of fine sand with5 $\mathrm{L}$ of synthetic wastewater with $1,2,3$, and $5 \%\left(\mathrm{~V}_{\text {diesel }} / \mathrm{V}_{\mathrm{water}}\right)$ diesel concentrations. Another pail without diesel acted as a control. The synthetic wastewater was kept at a level $5 \mathrm{~cm}$ above the sand to simulate a freesurface flow system. Physical observation was performed for two weeks, to determine the ability of plant to tolerate diesel contamination.

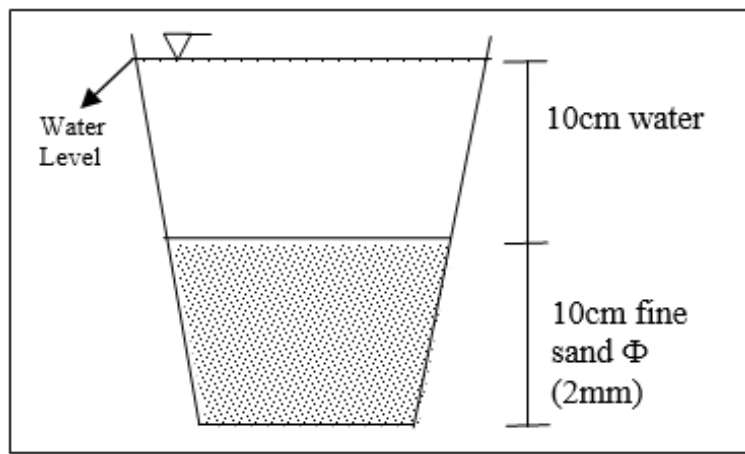

Figure 2: Free surface flow system.

For the sub-surface flow system, each pail was planted with plants of in $3 \mathrm{~kg}$ of fine sand with $2 \mathrm{~L}$ of synthetic wastewater with $1,2,3$, or $5 \%$ (Vdiesel/Vwater) diesel 
concentrations. Another pail without standard diesel served as a control.

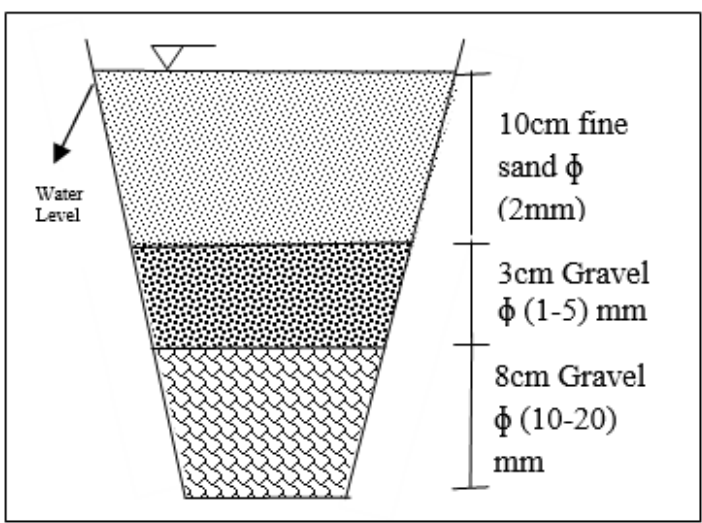

Figure 3: Sub surface flow system.

\section{Results and discussion - propagation of phragmites australis and Helianthus annuus}

\section{Phragmites australis}

The wet and dry plant weight was measured from the age of one day to 42 days to determine the plant biomass, the wet and dry weight increase from the second week.

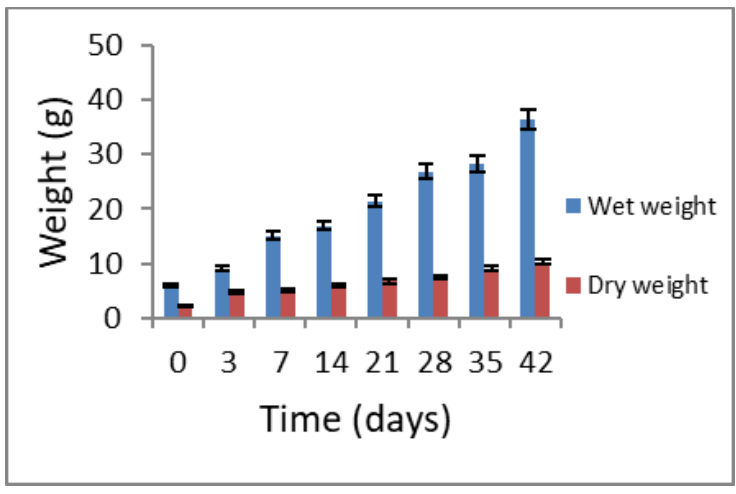

Figure 4: Wet weight and dry weight of phragmites communis during the propagation period.

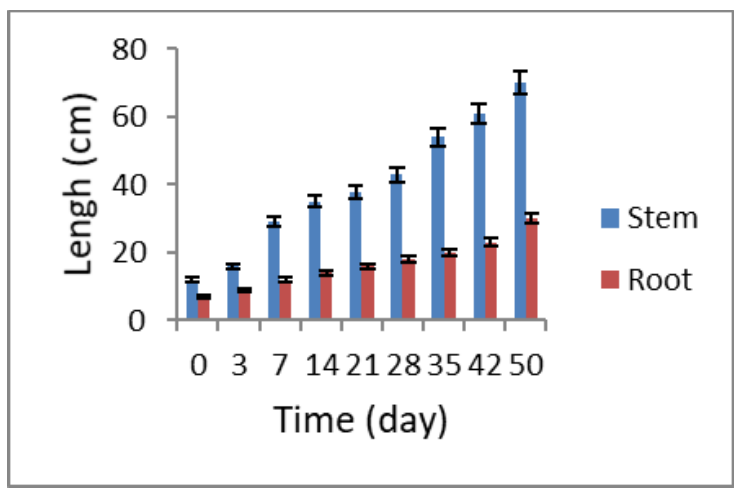

Figure 5: Stem length and root length of phragmites communis during plant propagation period.

The correlation formula was $y=3.919 x-5.299$, with the correlation factor $\mathrm{R}=0.945$ between wet and dry weight.

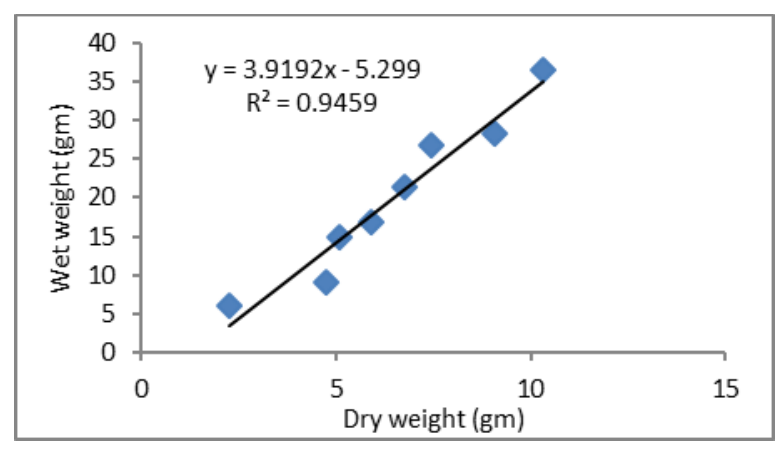

Figure 6: The correlation formula between wet and dry weight of phragmites communis during plant propagation.

\section{Helianthus annuus}

The wet and dry plant weight was measured from the age of 7 days to 50 days to determine the plant biomass, the wet and dry weight increase from the second week and decrease at 50 days.

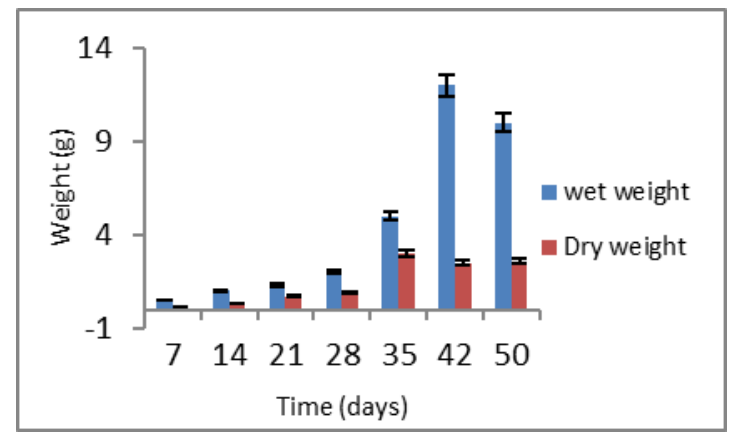

Figure 7: Wet weight and dry weight of Helianthus annuus during the propagation period.

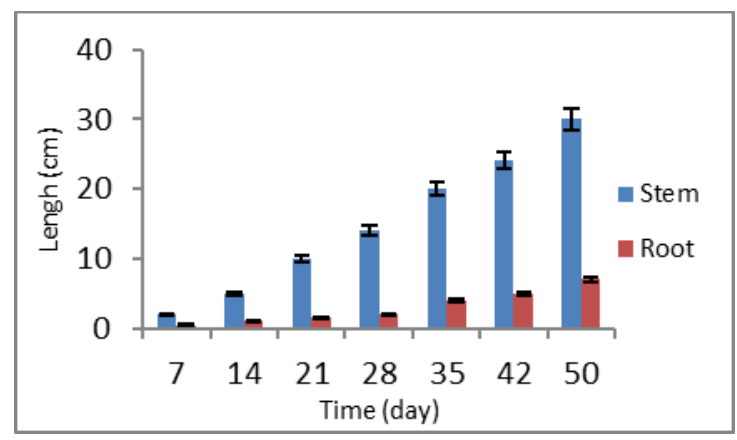

Figure 8: Stem length and root length of Helianthus annuus during plant propagation period.

The correlation formula was $y=3.188 x-0.057$, with the correlation factor $\mathrm{R}=0.683$ between wet and dry weight. 


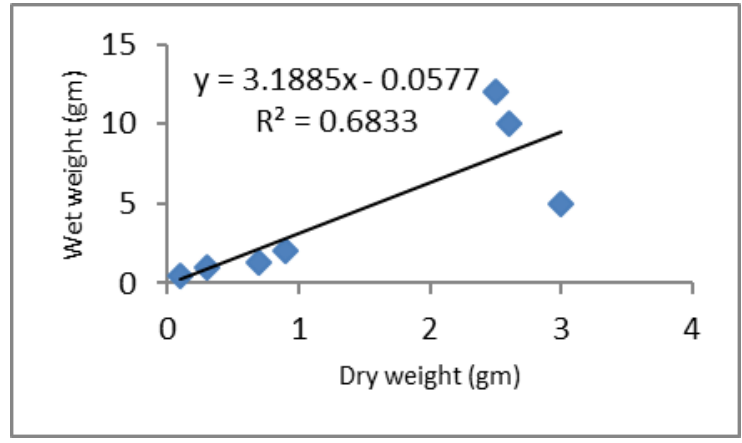

\section{Preliminary Test of Phytotoxicity}

After two weeks of observation on both free- and subsurface flow systems, the percentage of withered plants after exposure to diesel contaminants . The number of withered plants was recorded and the percentage of withered plants was determined using Equation:

Withered plant $\%=\frac{\text { No.of withered plants }}{\text { No.of total plants }} \times 100$

Figure 9: The correlation between wet and dry weight of Helianthus annuus during plant propagation.

\section{Diesel concentration}

$\underline{\text { Control }}$ $2 \%$ $3 \%$ $5 \%$

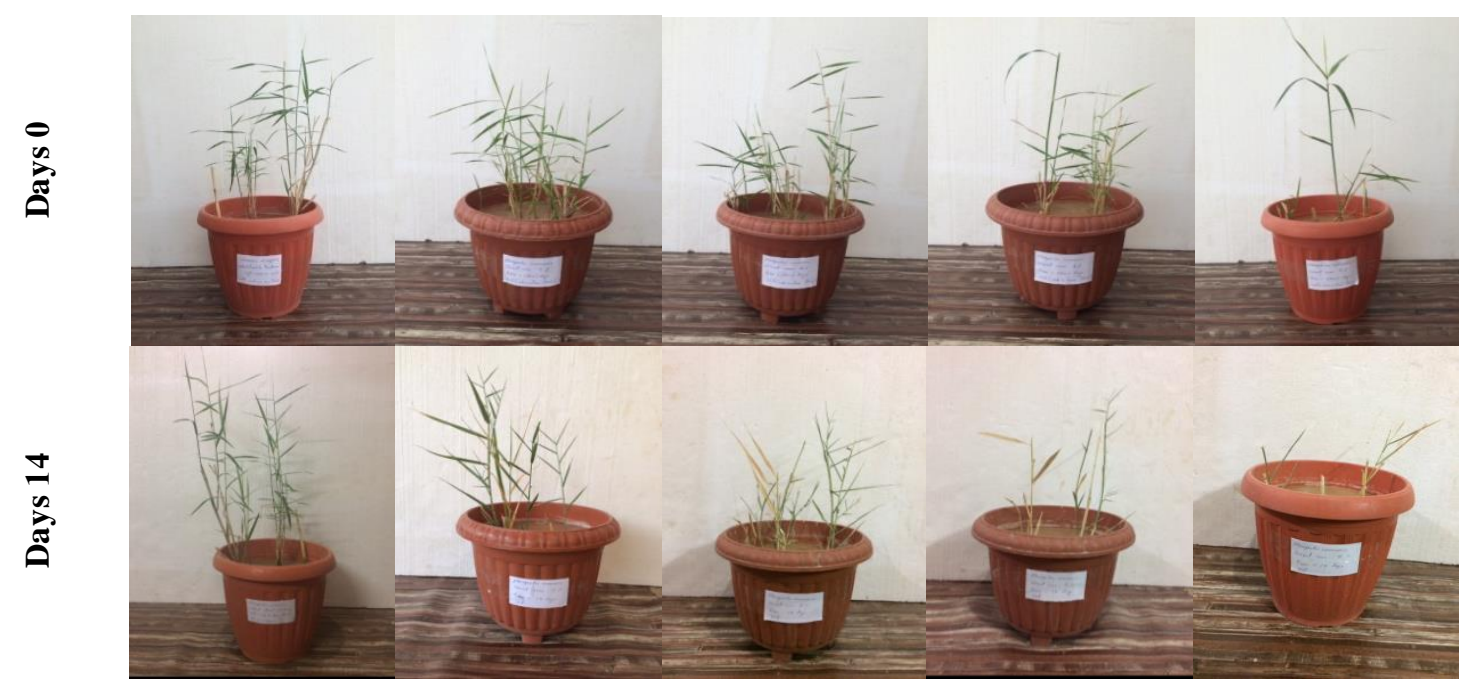

Figure 10: Withered plants in the sub- surface flow system after 14 days of observation in the preliminary test of phragmites communis.

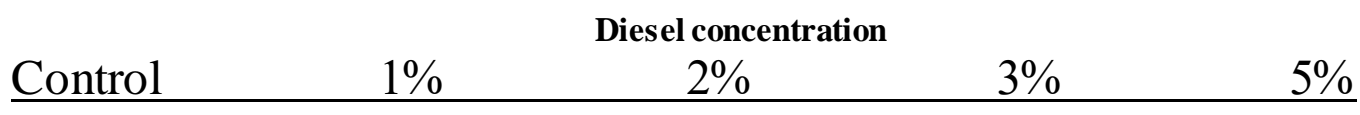

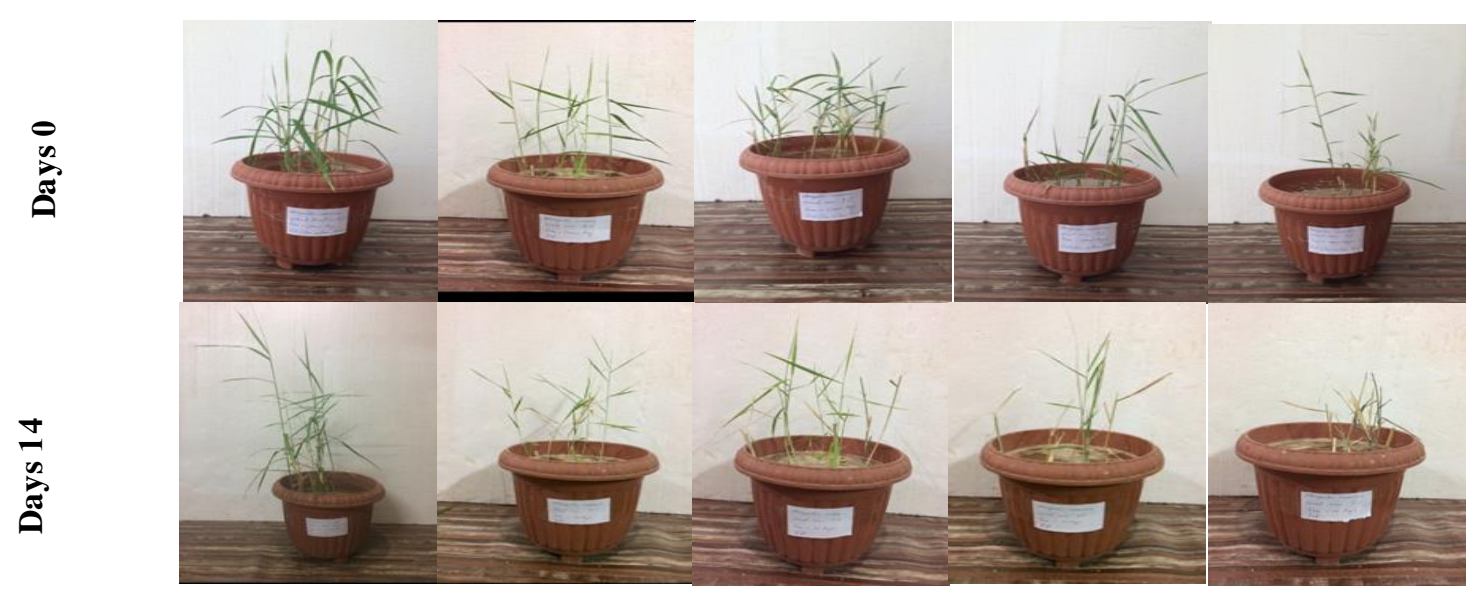

Figure 11: Withered plants in the free surface flow system after 14 days of observation in the preliminary test of phragmites communis.

Table 3: Metal foam properties. 


\begin{tabular}{cccc}
\hline No. & $\begin{array}{c}\text { Conc }(\mathbf{x}) \\
\left(\mathbf{V}_{\text {diesel }} / \mathbf{V}_{\text {water }}\right)\end{array}$ & $\begin{array}{c}\text { Percentage of } \\
\text { withered } \\
\text { plants in SSF }\end{array}$ & $\begin{array}{c}\text { Percentage of } \\
\text { withered } \\
\text { plants in FSF }\end{array}$ \\
\hline 1 & $0 \%$ & 0 & 0 \\
2 & $1 \%$ & $10 \%$ & $15 \%$ \\
3 & $2 \%$ & $33 \%$ & $40 \%$ \\
4 & $3 \%$ & $43 \%$ & $67 \%$ \\
5 & $5 \%$ & $67 \%$ & $100 \%$
\end{tabular}

For the FSF and SSF, the minimum percentage of withered plants $(15 \%)$ occurred at $(1 \%)$ diesel concentration, it increase at (3\%) in FSF at percentage (67\%) and after two weeks of exposure to diesel at (5\%) diesel concentration, $(100 \%)$ plant is withered (no plant phragmites communis survived). In SSF the minimum percentage of withered plants, $(10 \%)$ occurred at $(1 \%)$ diesel concentration, it increase and at $(5 \%)$ concentration diesel, withered plant percentage was $(\% 67)$.

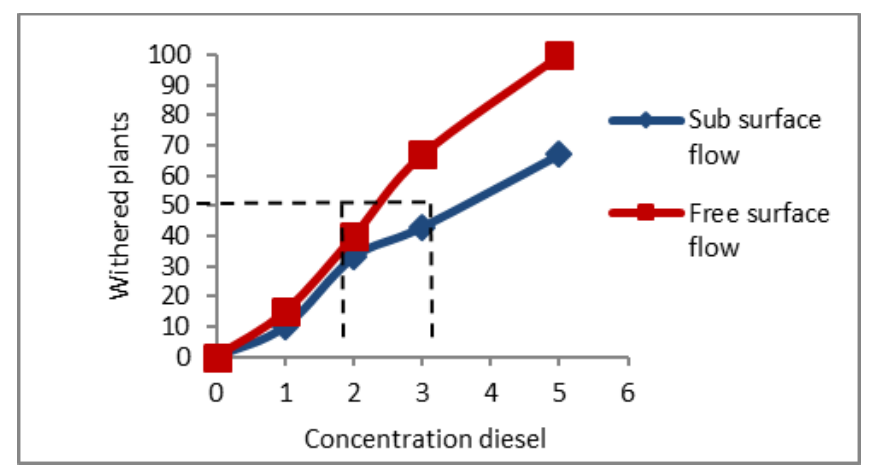

Figure 12: Percentage of withered plants of phragmites communis during the preliminary test

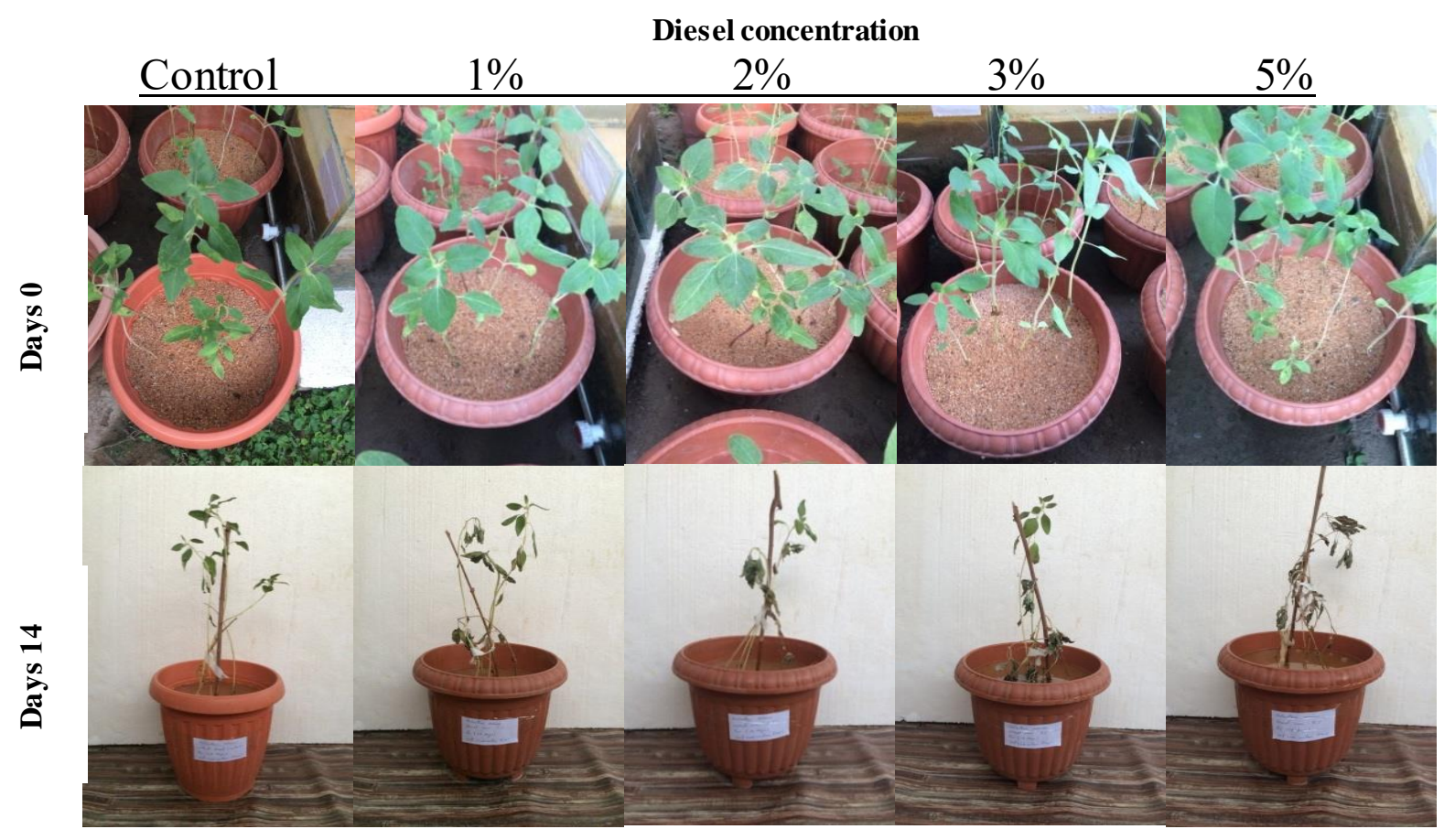

Figure 13: Withered plants in the sub-surface flow systemafter 14 days of observation in the preliminary test of Helianthus annuus.

\begin{tabular}{lllll} 
Control & $1 \%$ & $2 \%$ & $3 \%$ & $5 \%$ \\
\hline
\end{tabular}




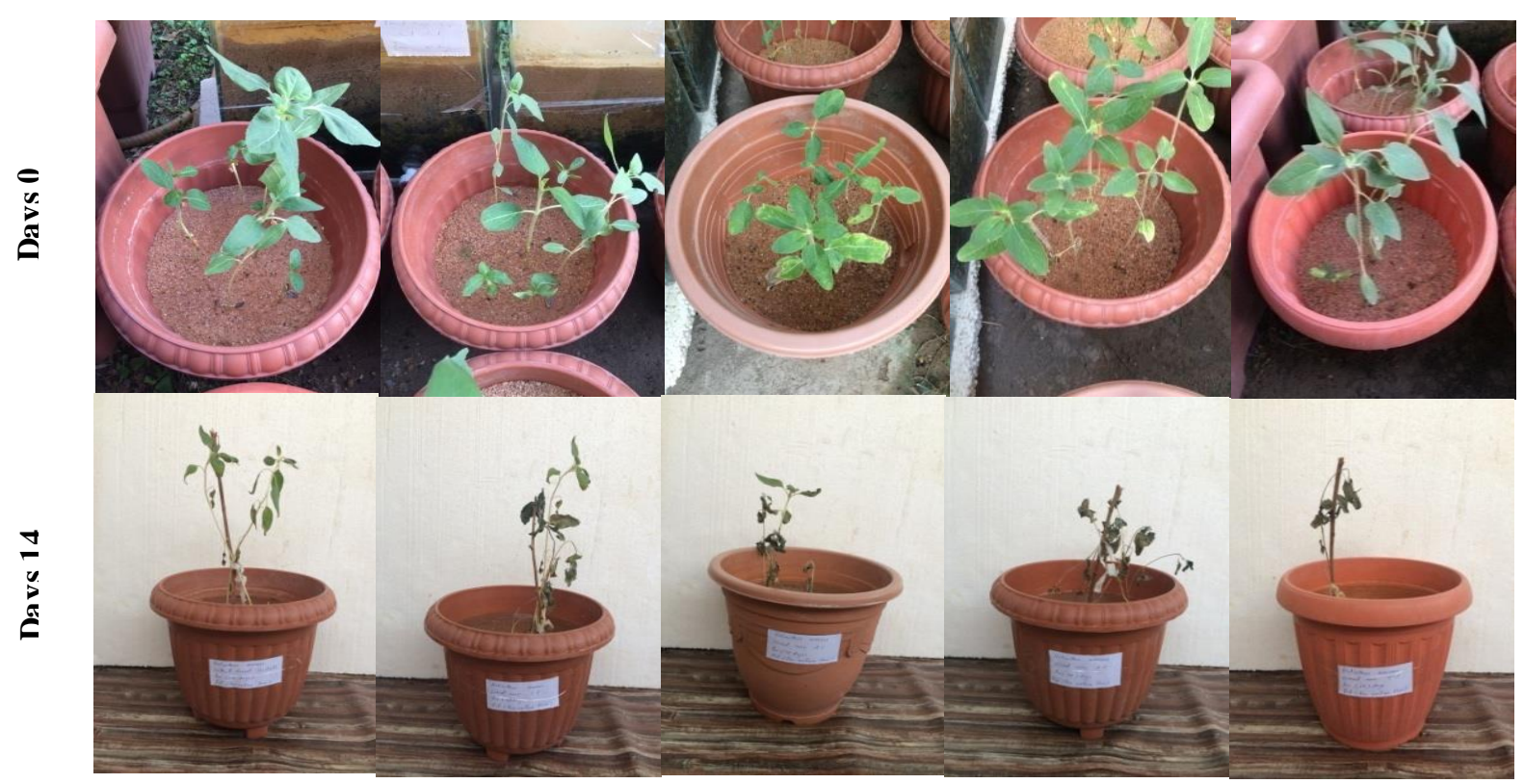

Figure 14: Withered plants in the free surface flow systemafter 14 days of observation in the preliminary test of Helianthus annuus.

Table 4: Preliminary tests of diesel exposure using Helianthus annuus .

\begin{tabular}{cccc}
\hline No. & Conc $(\mathbf{x})\left(\mathbf{V}_{\text {diesel }} / \mathbf{V}_{\text {water }}\right)$ & $\begin{array}{c}\text { Percentage of } \\
\text { withered } \\
\text { plants in SSF }\end{array}$ & $\begin{array}{c}\text { Percentage of } \\
\text { withered } \\
\text { plants in FSF }\end{array}$ \\
\hline 1 & $0 \%$ & 0 & 0 \\
2 & $1 \%$ & $20 \%$ & $33 \%$ \\
3 & $2 \%$ & $70 \%$ & $75 \%$ \\
4 & $3 \%$ & $75 \%$ & $100 \%$ \\
5 & $5 \%$ & $100 \%$ & $100 \%$
\end{tabular}

For the free-surface flow system, the minimum percentage of withered plants (33\%) occurred at $1 \%$ diesel concentration after two weeks and at the $(3 \%)$ diesel concentration, no Helianthus annuus plants survived. After two weeks of exposure to diesel in the sub-surface flow system, the minimum percentage of withered plants was $(20 \%)$ at the $(1 \%)$ diesel concentration and it is increase, reached $(100 \%)$ at the $(5 \%)$ diesel concentration.

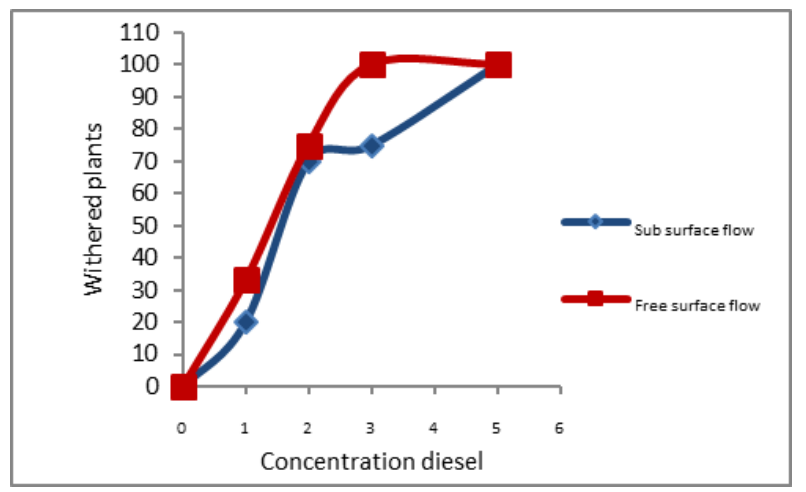

Figure 15: Percentage of withered plants of Helianthus annuus during the preliminary test.

\section{Conclusion}

The preliminary test conducted to assess the ability of phragmites communis and Helianthus annuus survive with different diesel concentration in two systems of SSF and FSF .The results clearly show whenever concentration increase, the number of withered plant also increase. The plant in SSF resistant diesel compared FSF and Phragmites communis is better in phytoremediation than helianthus annuus.

\section{References}

1 .Agency for Toxic Substances and Disease Registry (ATSDR) 1999. Toxicological Profile for total petroleum hydrocarbons (TPH). Atlanta, GA: U.S. Department of Health and Human Services, Public Health Service. ToxFAQsTM for Total Petroleum Hydrocarbons (TPH) Hidrocarburos Totales de Petróleo (TPH) August.

2 .Ali H., Khan E., Sajad M.A., 2013. Phytoremediation of heavy metals - Concepts and applications. Chemosphere 91, 869-881. 
3 .Antonio Cristaldi, Gea Oliveri Conti, Eun Hea Jho, Pietro Zuccarello, Alfina Grasso, Chiara Copat, Margherita Ferrante Cristaldi, A., Conti, G.O., Jho, E.H., Zuccarello, P., Grasso, A., Copat, C., Ferrante, M. 2017. Phytoremediation of contaminated soils by heavy metals and PAHs. A brief review. Environmental Technology \& Innovation http://dx.doi.org/10.1016/j.eti.2017.08.002

4 .Asia Fadhile Al-Mansoory 1,4 \& Mushrifah Idris 2 \& Siti Rozaimah Sheikh Abdullah3 \& Nurina Anuar3 2015. Phytoremediation of contaminated soils containing gasoline using Ludwigia octovalvis (Jacq.) in greenhouse pots. Environ Sci Pollut Res Int. 2017 May;24(13):1199812008. doi: 10.1007/s11356-015-5261-5. Epub Sep 2.

5 .Asmita V. Patil a, Jyoti P.Jadhav 2013. Evaluation of phytoremediation potential of Tagetes patula $\mathrm{L}$. for the degradation of textile dye Reactive Blue 160 and assessment of the toxicity ofdegraded metabolites by cytogenotoxicity. Chemosphere 92: 225-232.

6 .Barcelo J., Poschenrieder C., 2003. Phytoremediation: principles and perspectives. Contributions to science, 2 (3): 333-344 (2003) Institut d'Estudis Catalans, Barcelona .

7 .Barrutia, O., Garbisu, C., Epelde, L., Sampedro, M.C., Goicolea, M.A., Becerril, J.M., 2011. Plant tolerance to diesel minimizes its impact on soil microbial characteristics during rhizoremediation of dieselcontaminated soils. Sci. Total Environ. 409, 4087-4093.

8 .Cao B, Nagarajan K, Loh KC. 2009. Biodegradation of aromatic compounds: current status and opportunities for biomolecular approaches. Appl Microbiol Biotechnol 85(2):207-228 .

9 .Cunningham S.D., Ow D.W., 1996. Promises and prospects for phytoremediation. Plant Physiology 110, 715-719.

10 .Eman A. Diab. 2008. Phytoremediation of Oil Contaminated Desert Soil Using the Rhizosphere Effects. Global Journal of Environmental Research 2 (2): 66-73.6

11 .Fiorentino N., Fagnano M., Ventorino V., Pepe O., Zoina A., Impagliazzo A., Spigno P., 2012. Assisted phytoextraction of heavy metals: compost and Trichoderma effects on giant reed uptake and soil quality. Plant Soil Environ.

12 .Gerhardt K.E., Huang X.D., Glick B.R., Greenberg B.M., 2009. Phytoremediation and rhizoremediation of organic soil contaminants: Potential and challenges. Plant Science 176 (2009) 20-30.

13 .Glick, 2010. Research review paper; using soil bacteria to facilitate phytoremediation, biotechnol. Adv. 28,367 374.
14 .Heady, H. F. 1957. The Measurement and Value of Plant Height in the Study of Herbaceous Vegetation. Ecology 38(2): 313-320.

15 .Huesemann, M., Hausmann, T., Fortman, T., Thom, R., Cullinan, V., 2009. In situ phytoremediation of PAHand PCB-contaminated marine sediments with eelgrass (Zostera marina). Ecol. Eng. 35, 1395-1404.

16 .I.Alkorta1, J. Herna' ndez-Allica2, J.M. Becerril3, I. Amezaga3, I. Albizu2 \& C. Garbisu2,* 2004. Recent findings on the phytoremediation of soils contaminated with environmentally toxic heavy metals and metalloids such as zinc, cadmium, lead, and arsenic . Reviews in Environmental Science and Bio/Technology 3: 71-90.

17 .Israa Abdul Wahab Al-Baldawi a,b,d,*, Siti Rozaimah Sheikh Abdullah a, Fatihah Suja b, Nurina Anuar a, Idris Mushrifah c. 2013. Comparative performance of free surface and sub-surface flow systems in the phytoremediation of hydrocarbons using Scirpus grossus. Journal of Environmental Management 130 , 324e330

18 .Israa Abdul Wahab Al-Baldawia,b,d,*, Siti Rozaimah Sheikh Abdullaha, Fatihah Sujab, Nurina Anuara and Mushrifah Idrisc. 2015. Phytoremediation of contaminated ground water using Typha angustifolia. Water Practice \& Technology Vol 10 No 3 (616) doi: 10.2166/wpt.072.

19 .Israa Abdulwahab Al-Baldawi a,d, Siti Rozaimah Sheikh Abdullah a, Nurina Anuara,*, Fatihah Suja b, Idris Mushrifah c. 2015. Phytodegradation of total petroleum hydrocarbon (TPH) in diesel-contaminated water using Scirpus grossus. Ecological Engineering $74,463-473$.

20 .Israa Abdulwahab Al-Baldawi, Siti Rozaimah Sheikh Abdullah, Nurina Anuar, Fatihah Suja and Mushrifah Idris 2013. Performance assessment of pilot horizontal subsurface flow constructed wetlands for removal of diesel from wastewater by Scirpus grossus. Water science \& Technology 68.(10)

21 .Is raa Abdulwahab Al-Baldawia,d,*, Siti Rozaimah Sheikh Abdullaha, Nurina Anuara, Fatihah Sujab, Mushrifah Idris c. 2013.

A phytotoxicity test of bulrush (Scirpus grossus) grown with diesel contamination in a free-flow reed bed system Journal of Hazardous Materials 252- 253 , 64- 69.

22 .Kabra, A. N., Khandare,R. V Sanjay, P. Govindwar, S.P.2013 Development of a bioreactor for remediation of textile effluent and dye mixture a plantebacterial synergistic stategy. Water res earch 47, 1035-1048.

23 .Kah Aik Tan, Norhashimah Morad, and Jie Qi Ooi, 2016. Phytoremediation of Methylene Blue and Methyl Orange Using Eichhornia crassipes. International Journal of Environmental Science and Development, Vol. 7, No. 10 , October. 
24 .Kavamura V.N., Esposito E., 2010. Biotechnological Strategies Applied to the Decontamination of Soils Polluted with Heavy Metals. Biotechnology Advances, Volume 28, pp 61-69.

25 .Khan A, Khan S, Khan M, Qamar Z, Waqas M. 2015. The uptake and bioaccumulation of heavy metals by food plants, their effects on plants nutrients, and associated health risk: a review. Environ Sci Pollut R 22 (18):1377213799.

26 .Kidd PS, Dominguez-Rodriguez MJ, Diez J, Monterroso C. 2007. Bioavailability and plant accumulation of heavy metals and phosphorus in agricultural soils amended by long-term application of sewage sludge. Chemosphere 66(8):1458-1467

27 .Leung H.M., Wang Z.W., Ye Z.H., Yung K.L., Peng X.L., Cheung K.C., 2013. Interactions Between Arbuscular Mycorrhizae and Plants in Phytoremediation of Metal-Contaminated Soils: A Review. Pedosphere 23(5): 549-563, 2013.

28 .Liu R., Xiao N., Wei S., Zhao L., An J., 2014. Rhizosphere effects of PAH-contaminated soil phytoremediation using a special plant named Fire Phoenix. Science of the Total Environment 473-474 (2014) 350-358.

29 .Liu, X., Wang, Z., Zhang, X., Wang, J., Xu, G., Cao, Z., Zhong Ch Su, P., 2011. Degradation of dieseloriginated pollutants in wetlands by Scirpus triqueter and microorganisms. Ecotoxicol. Environ. Saf. 74, 19671972.

30 .Mahar A., Wang P., Ali A., Awasthi M.K., Lahori A.H., Wang Q., Li R., Zhang Z., 2016. Challenges and opportunities in the phytoremediation of heavy metals contaminated soils: A review. Ecotoxicology and Environmental Safety $126,111-121$.

31 .Moreira, I., Oliveira, O., Triguis, J., Santos, A., Queiroz, A., Martins, C., Silva, C., Jesus, R., 2011. Phytoremediation using Rhizophora mangle $\mathrm{L}$. in mangrove sediments contaminated by persistent total petroleum hydrocarbons (TPHs). Microchem. J. 99, 376382.

32 .Nadali Alavi1, Iman parseh2,*, Mehdi Ahmadi3, Nematollah Jafarzadeh3, Ahmad Reza Yari4, Mehrangiz Chehrazi5, Mostafa Chorom5, 2017 . Phytoremediation of Total Petroleum Hydrocarbons From Highly Saline and Clay Soil Using Sorghum halepense (L.) Pers. and Aeluropus littoralis (Guna) Parl. Soil and Sediment Contamination: An International Journal Volume 26, Issue 1 .

33 .Nadya, H.A.S., Siti Rozaimah, S.A., Nur 'Izzati I., Omar H.J., 2014 Preliminary Test of Hydrocarbon
Exposure Eleocharis Ochrostachys in Phytoremediation Process. Aust. J. Basic \& Appl. Sci., 8(19): 26-29.

34 .Newman L.A., Reynolds C.M., 2004. Phytodegradation of organic compounds, Curr Opin Biotechnol 15 , pp. 225-230.

35 .Ray R. Hinchman, M. Cristina Negri, Edward G. Gatliff.,2013 . phytoremediation: using green plants to clean up contaminated soil, groundwater, and wastewater. Argonne National Laboratory and Applied Natural Sciences, Inc. 68 dffggbb.10 .

36 .Rosedale's Nurseries Inc. 2012. The Rosedale plantsman's guide to the measurement of nursery plant sizes.

www.rosedalenurseries.com/Guides/measurement_of_siz es_redo.pdf

37 .Rouvière, F., Buleté, A., Cren-Olivé, C. \& Arnaudguilhem, C. 2012 Multiresidue analys is of aromatic organochlorines in soil by gas chromatography-mass spectrometry and QuEChERS extraction based on water/dichloromethane partitioning. Comparison with accelerated solvent extraction. Talanta, 93, 336-344.

38 .Salmi Nur Ain Sanusi ; Siti Rozaimah Sheikh Abdullah; Mushrifah Idris 2012. Preliminary testof phytoremediation of hydrocarbon contaminated soil using paspalum vaginatum sw. Department of Chemical \& Process Engineering, School of Environmental \& Natural Resource Sciences Australian Journal of Basic and Applied Sciences 6(1): 39-42.

39 .San Miguel A., Ravanel P., Raveton M., 2013. A comparative study on the uptake and translocation of organochlorines by Phragmites australis. Journal of Hazardous Materials, Volumes 244-245, 15 January 2013, Pages 60-69.

40 .Schnoor, J.L., Licht, L.A., McCutcheon, S.C., Wolfe, N.L., Carreira, L.H., 1995. Phytoremediation of organic and nutrient contaminants. Environ. Sci. Technol. 29, $318 \mathrm{~A}-323 \mathrm{~A}$.

41 .Schwartz, D. 2012. Measuring plant growth. http://www.sciencebuddies.org/science,

airprojects/project_ideas/PlantBio_measuring_growth.sht ml,11 July .

42 .Sharma P., Pandey S., 2014. Status of Phytoremediation in World Scenario. International Journal of Environmental Bioremediation \& Biodegradation, Vol. 2, No. 4, 178-191.

43 .Shimp J.F., Tracy J.C., Davis L.C., Lee E., Huang W., Ericks on L.E.,1993. Beneficial Effects of Plants in the Remediation of Soil and Groundwater Contaminated with Organic Materials Crit. Rev. in Environmental Science and Technology 23, 41-77. 
44 .Sreelali G., Jayanthi R., 2017. Review on phytoremediation technology for removal of soil contaminant. Indian J.Sci.Res. 14 (1): 127-130, 2017.

45 .Susarla S., Medina V.F., McCutcheon S.C., 2002. Phytoremediation: An ecological solution to organic chemical contamination. Ecological Engineering 18,647658 .

46 .Tangahu B. V., Abdullah S. R. S., Basri H., Idris M., Anuar N., Mukhlisin M., 2011 . A review on heavy metals (As, $\mathrm{Pb}$, and $\mathrm{Hg}$ ) uptake by plants through phytoremediation. International Journal of Chemical Engineering 2011, Article ID 939161, 31 pp.

47 .Tunçtürk, M., Tunçtürk, R., Yildirim, B. \& Çiftçi, V. 2011 Changes of micronutrients, dry weight and plant development in canola (Brassica napus L.) cultivars under salt stress. Academic Journals African Journal of Biotechnology 10(19): 3726-3730.

48 .USEPA 2000b. Wastewater Technology Fact Sheet, Wetlands: Subsurface Flow. EPA-832-F-00-023 Washington, http://water.epa.gov/scitech/was tetech/upload/2002_06_2 8 mtb_wetlandssubsurface_flow.pdf. . [03 May 2011].

49 .Van Oosten M.J., Maggio A., 2014. Functionalbiology of halophytes in the phytoremediation of heavy metal contaminated soils. Environmental and Experimental Botany $111,135-146$.

50 .YennR, BorahM, BoruahHPD, RoyAS, Baruah R, Saikia N, SahuOP, Tamuli AK. 2014. Phytoremediation of abandoned crude oil contaminated drill sites of Assam with the aid of a hydrocarbon-degrading bacterial formulation. Int J Phytorem 16(7-12):909-925.

51 .Zhang H., Zheng L.C., Yi X.Y., 2009."Remediation of soil co-contaminated with pyrene and cadmium by growing maize (Zea mays L.)". Int. J. Environ. Sci. Tech., 6, 249-258.

52. Zhang Yu X., Dong Gu J., 2006. Uptake, metabolism, and toxicity of methyl tert-butyl ether (MTBE) in weeping willows. Journal of Hazardous Materials, Volume 137, Issue 3, October 2006, Pages 1417-1423. . [20 Jun 2012].

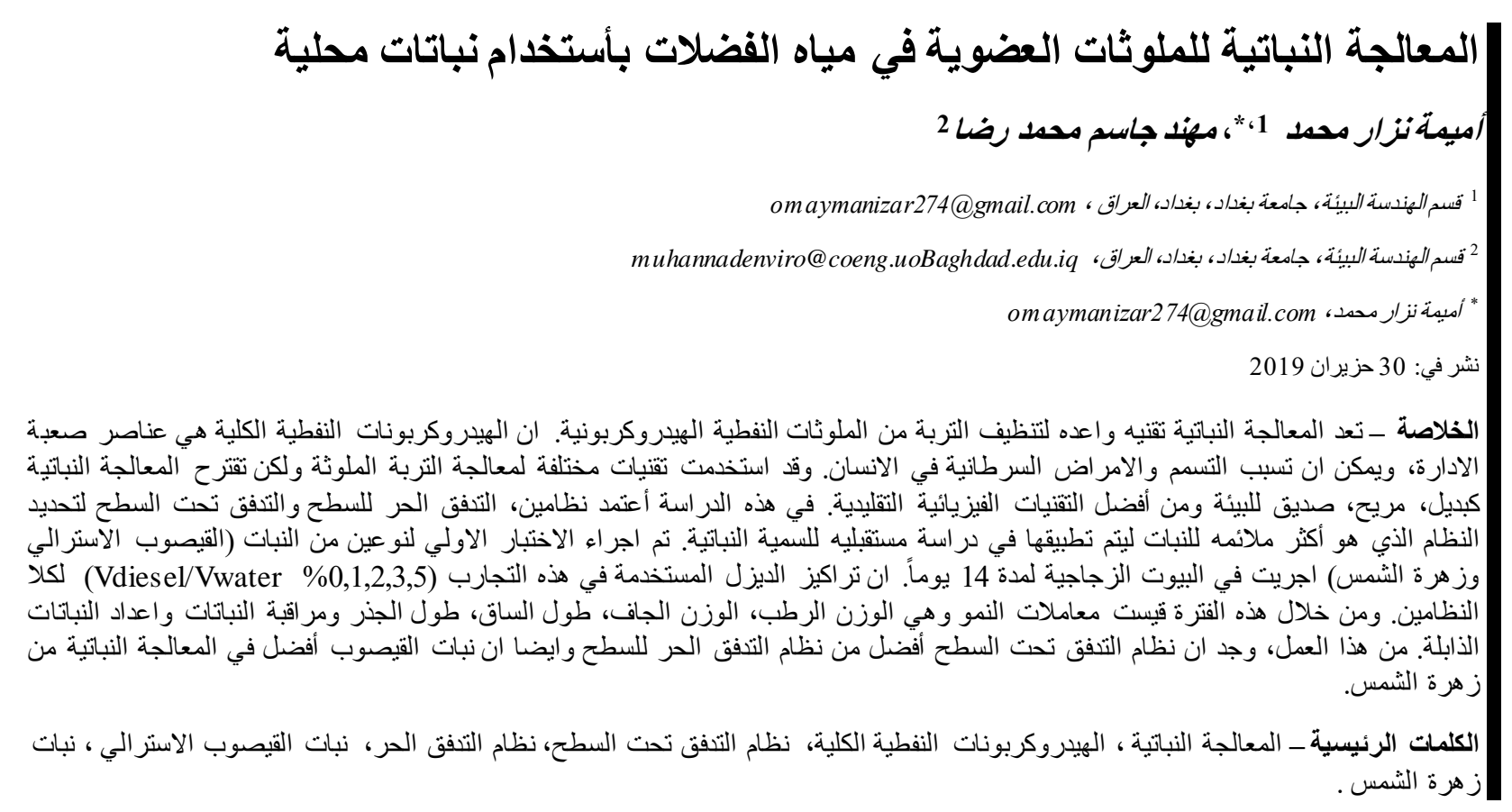

